\title{
Analisa Data Penerimaan Siswa Pada Perguruan Tinggi Melalui Jalur SNMPTN Menggunakan Algoritma Fuzzy C-Means ( Studi Kasus : SMAN 5 Kota Bengkulu)
}

\author{
Aan Herwansah ${ }^{1)}$, Herlina Latipa Sari ${ }^{2}$, Lena Elfianty ${ }^{3)}$ \\ Informatika, Ilmu Komputer, Universitas Dehasen \\ 1. aanherwansah4@gmail.com*, 2 herlinalatipasari@unived.ac.id, ${ }^{3}$ lena.elfianty@unived.ac.id
}

\begin{abstract}
SMA Negeri 5 Bengkulu City is one of State Senior High Schools in Bengkulu City that has been accredited A with a total of 58 educators and 23 administrative staff and employees. In addition, SMA Negeri 5 Bengkulu City has also won many achievements both in academics (graduates of SMA N 5 Bengkulu City are accepted at the best universities in Indonesia through test and non-test pathways) as well as in the fields of science (Olympics), Sports, IMTAQ and the arts for the provincial and national levels. Application of student admissions data in higher education through SNMPTN using Fuzzy C-Means Algorithm at SMA N 5 Bengkulu City is an application that can help analyze data grouping based on student admission data into 3 groups. Data Analysis of Student Admissions in higher education through SNMPTN was made using the Visual Basic.Net programming language and SQL Server 2008 database by applying the Fuzzy C-Means algorithm. This application is able to provide information on the results of the analysis of student admissions at Higher Education through SNMPTN. The more data on student admissions in Higher Education, the more accurate the grouping results. Based on the results of the tests that have been carried out, the Application of Student Admission Data in Higher Education through SNMPTN can provide information on the results of data grouping divided into 3 groups, namely high, medium and low.
\end{abstract}

Keywords: Analysis of Student Admission, SNMPTN, Fuzzy C-Algorithm Means, SMA N 5 Bengkulu City.

\begin{abstract}
Abstrak
SMA Negeri 5 Kota Bengkulu merupakan salah satu Sekolah Menengah Atas Negeri di Kota Bengkulu yang telah terakreditasi A dengan jumlah pendidik 58 orang dan 23 orang tenaga administrasi dan karyawan. Di samping itu SMA Negeri 5 Kota Bengkulu juga telah meraih banyak prestasi baik dibidang akademis (lulusan SMA Negeri 5 Kota Bengkulu yang diterima di Perguruan Tinggi terbaik di Indonesia melalui jalur tes dan non tes) maupun bidang sains (Olimpiade), Olahraga, imtaq dan seni untuk tingkat provinsi maupun nasional. Aplikasi Data Penerimaan Siswa Pada Perguruan Tinggi Melalui jalur SNMPTN menggunakan Algoritma Fuzzy C-Means di SMA Negeri 5 Kota Bengkulu merupakan aplikasi yang dapat membantu menganalisis pengelompokan data berdasarkan data penerimaan siswa menjadi 3 kelompok. Analisa Data Penerimaan Siswa Pada perguruan Tinggi Melalui Jalur SNMPTN dibuat menggunakan bahasa pemrograman Visual Basic.Net dan Database SQL Server 2008 dengan menerapkan algoritma Fuzzy C-Means. Aplikasi ini mampu memberikan informasi hasil dari analisis penerimaan siswa pada Perguruan Tinggi melalui jalur SNMPTN. Semakin banyak data penerimaan siswa pada Perguruan Tinggi, semakin akurat hasil pengelompokannya. Berdasarkan hasil pengujian yang telah dilakukan, Apikasi Data Penerimaan Siswa Pada Perguruan Tinggi Melalui Jalur SNMPTN dapat memberikan informasi hasil pengelompokan data dibagi menjadi 3 kelompok yaitu tinggi, sedang dan rendah.
\end{abstract}

Kata Kunci : $\quad$ Analisis, Penerimaan Siswa, Jalur SNMPTN, Algoritma Fuzzy C-Means, SMA Negeri 5 Kota Bengkulu

\section{Pendahuluan}

Seiring kemajuan teknologi informasi data yang dapat digunakan dan juga dapat disebarkan secara global. Siapapun dan dimanapun pengguna informasi berada, dapat diambil dan digunakan data informasi tersebut. Sarana kerjasama antara pribadi atau kelompok satu dengan yang lainnya tanpa mengenal batas jarak dan waktu atau faktor lainnya yang dapat menghambat bertukar pikiran.

SMA Negeri 5 Kota Bengkulu merupakan salah satu Sekolah Menengah Atas Negeri di Kota Bengkulu yang telah terakreditasi A dengan jumlah pendidik 58 orang dan 23 orang tenaga administrasi dan karyawan. Di samping itu SMA Negeri 5 Kota Bengkulu juga telah meraih banyak prestasi baik bidang akademis (lulusan SMA Negeri 5 Kota Bengkulu yang diterima di Perguruan Tinggi Negeri terbaik di Indonesia melalui jalur tes dan non tes) maupun bidang sains (Olimpiade), olahraga, imtaq dan seni untuk tingkat provinsi maupun nasional.

Dalam membantu proses pengolahan data alumni SMA Negeri 5 Kota Bengkulu menggunakan aplikasi google form supaya para alumni bisa mengisi data dimanapun mereka berada dan bisa menggunakan smartphone/handphone mereka sendiri. Kemudian data yang telah diisi oleh alumni, akan diolah kembali untuk pelaporan arsip di SMA Negeri 5 Kota Bengkulu.

Dalam penelitian ini, penulis melakukan analisis terhadap data alumni siswa di SMA Negeri 5 Kota Bengkulu berdasarkan Perguruan Tinggi yang telah menerima siswa tersebut baik melalui jalur SBMPTN maupun jalur SNMPTN dengan cara melakukan pengelompokan data menjadi 3 
kelompok yaitu tinggi sedang, dan rendah. Dengan adanya pengelompokan ini tentunya dapat dijadikan pihak sekolah sebagai salah satu alat dalam menarik minat calon siswa baru.

Untuk melakukan proses pengelompokan tersebut, dibutuhkan metode klasterisasi yang terdapat di dalam data mining, salah satunya adalah Algoritma Fuzzy C-Means. Algoritma ini merupakan salah satu teknik pengelompokan data yang mana keberadaan tiap-tiap titik data dalam suatu cluster ditentukan oleh derajat keanggotaannya.

\section{Metode Penelitian}

Jenis penelitian yang akan digunakan adalah penelitian data kuantitatif (berbasis perhitungan angka dan statistika) dan kualitatif berdasarkan data deskriptif guna memahami suatu fenomena secara mendalam dengan menggunakan landasan teori sebagai panduan untuk memfokuskan penelitian. Adapun metode yang digunakan dalam menentukan kinerja Dosen Teladan yaitu metode waterfall dengan implementasi algoritma Fuzzy C -means

\subsection{Metode Waterfall}

Metode penelitian yang digunakan penulis adalah metode Waterfall. Metode waterfall sering dinamakan siklus hidup klasik (classic life cycle), dimana hal ini menggambarkan pendekatan yang sistematis dan juga berurutan pada pengembangan perangkat lunak, dimulai dengan spesifikasi kebutuhan pengguna lalu berlanjut melalui tahapantahapan perencanaan (planning), permodelan (modeling), konstruksi (construction), serta penyerahan sistem ke para pelanggan/pengguna (deployment), yang diakhiri dengan dukungan pada perangkat lunak lengkap yang dihasilkan. Metode waterfall memiliki beberapa tahapan [1]. dapat dilihat pada gambar 3.1.

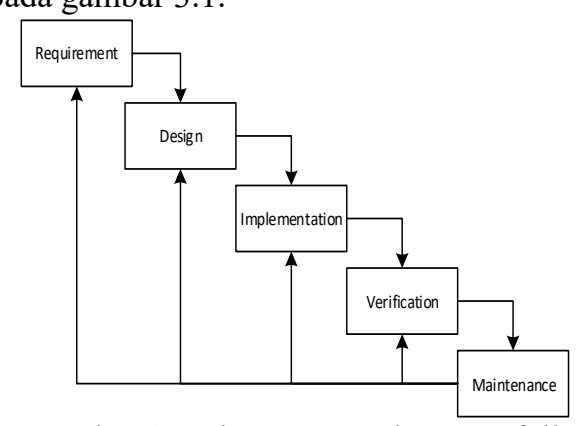

Gambar 1. Tahapan Metode Waterfall

Keterangan :

1. Analisa

Analisa dilakukan dengan menggunakan metode pengumpulan data yaitu observasi, wawancara, dan studi pustaka.

2. Design

Desain sistem pendukung keputusan berdasarkan hasil analisis permasalahan yang telah dilakukan sebelumnya pada tahap analisa. Perancangan sistem akan disesuaikan dengan metode yang digunakan, dalam hal ini metode yang digunakan adalah metode Fuzzy Fuzzy C-Means, sehingga rancangan sistem yang dibuat mengacu pada metode tersebut.

3. Coding dan Testing

Pengkodean dilakukan setelah rancangan sistem pendukung keputusan selesai dibuat. Pengkodean dilakukan dengan cara menerjemahkan bahasa analisa sistem ke dalam bahasa yang dikenali oleh komputer dengan menerapkan metode Fuzzy Fuzzy C-Means.

4. Penerapan

Tahapan ini bisa dikatakan final dalam pembuatan sebuah sistem. Setelah melakukan analisa, design dan pengkodean maka sistem yang sudah jadi akan digunakan oleh user.

5. Pemeliharaan

Pemeliharaan dilakukan untuk menjaga kestabilan fungsionalitas sistem yang dibuat.

\subsection{Data Mining}

Data mining merupakan proses iterative dan interaktif untuk menemukan pola atau model baru yang sempurna, bermanfaat dan dapat dimengerti dalam suatu database yang sangat besar (massive database). Data mining berisi pencarian trend atau pola yang diinginkan dalam database besar untuk membantu pengambil keputusan di waktu yang akan datang, pola-pola ini dikenali perangkat tertentu yang dapat memberikan suatu analisa data yang berguna dan berwawasan yang kemudian dapat dipelajari dengan lebih teliti, yang mungkin saja menggunakan perangkat pendukung keputusan yang lain [2].

\subsection{Algoritma Fuzzy C-Means (FCM)}

Fuzzy C-Means (FCM) adalah salah satu teknik pengclusteran data yang mana keberadaan tiap-tiap titik data dalam suatu cluster ditentukan oleh derajat keanggotaannya. Teknik ini pertama kali diperkenalkan oleh Jim Bezdek pada tahun 1981. Fuzzy Cluster Means (FCM) merupakan algoritma yang digunakan untuk melakukan clustering data sesuai berdasarkan keberadaan tiap-tiap titik data sesuai dengan derajat keanggotaannya [3].

Dalam logika fuzzy terdapat metode yang sering digunakan untuk mengklaster data, yaitu metode Fuzzy C-Means. Fuzzy C-Means adalah suatu metode pengklasteran data yang ditentukan oleh derajat keanggotaan [4]

2.4. Langkah- langkah Penyelesain Fuzzy C-Means Output dari FCM bukan merupakan fuzzy inference system, namun merupakan derajat pusat cluster dan beberapa derajat keanggotaan untuk tiaptiap titik data. Algoritma Fuzzy C-Means disusun dengan langkah sebagai berikut [5]

1. Input Data

Input data yang akan di cluster yaitu data training $(x)$ berupa matrik berukuran $n \times m$, dimana :

$n=$ jumlah data

$m=$ atribut setiap data 
$X_{i j}=$ data ke- $i(i=1,2, \ldots, \mathrm{n})$, atribut ke- $j(j=1$, $2, \ldots, \mathrm{m})$

2. Batasan
a. Jumlah Cluster (c)
b. Pangkat (w)
c. Maximum iterasi (Maxit)
d. Error terkecil yang diharapkan $(\mathcal{E})$
e. Fungsi objektif awal $\left(\mathrm{P}_{0}\right)$
f. Iterasi awal (t)

3. Membangkitkan bilangan random $\left(\mathrm{U}_{\mathrm{ik}}\right), \mathrm{i}=1$, $2, \ldots, \mathrm{n} ; \mathrm{k}=1,2, \ldots, \mathrm{c}$; sebagai elemen-elemen matrik partisi awal $\mathrm{U}$, dengan jumlah setiap nilai elemen kolom dalam satu baris adalah 1 (satu).

$$
\sum_{i=1}^{c} \mu_{c i}=1
$$

4. Menghitung pusat cluster $\mathrm{ke}-\mathrm{k}$ : $\mathrm{V}_{\mathrm{kj}}$ dengan $\mathrm{k}=$ $1,2, \ldots, c ;$ dan $\mathrm{j}=1,2, \ldots, \mathrm{m}$.

$$
V_{k j}=\frac{\sum_{i=1}^{n}\left(\left(\mu_{i k}\right)^{w} * X_{i j}\right.}{\sum_{i j}^{n}\left(\mu_{i k}\right)^{w}}
$$

5. Menghitung fungsi objektif pada iterasi ke-t, $P_{t}$

$$
P_{t}=\sum_{i=1}^{n} \sum_{k=1}^{c}\left(\left[\sum_{j=1}^{m}\left(X_{i j}-V_{k j}\right)^{2}\right]\left(\mu_{i k}\right)^{2}\right)
$$

6. Menghitung perubahan matrik partisi :

$$
=\frac{\left[\sum_{j=1}^{m}\left(x_{i j}-v_{k j}\right)^{2}\right]^{\frac{-1}{w-1}}}{\left.\sum_{i=1}^{n} \sum_{k=1}^{c}\left(\left[\sum_{j=1}^{m}\left(X_{i j}-V_{k j}\right)^{2}\right]\left(\mu_{i k}\right)^{2}\right)\right]^{\frac{-1}{w-1}}}
$$

Dengan $\mathrm{i}=1,2, \ldots, \mathrm{n}$; dan $\mathrm{k}=1,2, \ldots, \mathrm{c}$

7. Mengecek kondisi berhenti :
a. Jika : $\left(\left|\mathrm{P}_{\mathrm{t}}-\mathrm{P}_{\mathrm{t}-1}\right|<\mathcal{E}\right)$ atau ( $\mathrm{t}>\max$ iterasi) maka berhenti
b. Jika tidak : $\mathrm{t}=\mathrm{t}+1$, ulangi langkah ke 4 (menghitung $\mathrm{V}_{\mathrm{kj}}$ )

\subsection{Teknik Analisa Data}

Adapun tahapan-tahapan proses dari Fuzzy C-

Means antara lain :

1) Menginputkan data yang akan di cluster $X$, berupa matriks berurutan $\mathrm{n} \times \mathrm{m}$.

Data yang diperoleh dari SMA Negeri 5 Kota Bengkulu dipecah berdasarkan data penerimaan siswa pada Perguruan tinggi melalui jalur SNMPTN. Sedangkan atribut atau kriteria yang dijadikan sebagai parameter pengelompokan ada 2 yaitu nilai rata-rata Raport dan jumlah prestasi akademik dan non. Adapun sampel yang digunakan sebanyak 10 data seperti

\begin{tabular}{|l|c|c|c|}
\hline \multicolumn{1}{|c|}{ Nama Siswa } & $\begin{array}{c}\text { Perguruan } \\
\text { Tinggi }\end{array}$ & Prestasi & $\begin{array}{c}\text { Nilai } \\
\text { Rata- } \\
\text { rata }\end{array}$ \\
\hline Izzah Azizah & UNIB & 0 & 87,93 \\
\hline Safitri Anggraini & UNIB & 0 & 85,00 \\
\hline Defriani Yolanda & UNIB & 0 & 88,00 \\
\hline $\begin{array}{l}\text { Bambang } \\
\text { Kurniawan }\end{array}$ & IPB & 3 & 88,86 \\
\hline Ika Puji Lestari & UNS & 0 & 88,86 \\
\hline
\end{tabular}

\begin{tabular}{|l|c|c|c|}
\hline $\begin{array}{l}\text { Satria Dimas } \\
\text { Syaiful }\end{array}$ & UNIB & 1 & 88,64 \\
\hline Marchelia Zafira & $\begin{array}{c}\text { Universitas } \\
\text { Brawijaya }\end{array}$ & 0 & 89,79 \\
\hline Titis Yoga Safitri & UNDIP & 0 & 91,36 \\
\hline Delsa Ardianti & UNIB & 1 & 88,07 \\
\hline $\begin{array}{l}\text { Riesa Aliah } \\
\text { Tuhfan }\end{array}$ & $\begin{array}{c}\text { Universitas } \\
\text { Brawijaya }\end{array}$ & 0 & 89,36 \\
\hline
\end{tabular}

Tabel 1. Data Penerimaan Siswa

Dari Tabel 3.1. didapatkan matriks 10 x 3 .

2) Batasan:

Jumlah cluster : 3 (Tinggi, Sedang dan Rendah)

Pangkat atau pembobot : 2

Maksimum Iterasi : 3

Error terkecil yang diharapkan 0,1

Fungsi objektif awal $: \mathrm{P}_{0}=0$

Iterasi awal $: \mathrm{t}=1$

3) Membangkitkan bilangan random sebagai elemen matrik partisi awal $\mathrm{U}$.

$$
\sum_{i=1}^{c} \mu_{c i}=1
$$

4) Menghitung pusat cluster $\mathrm{ke}-\mathrm{k}=\mathrm{Vkj}$ menggunakan persamaan

$$
V_{k j}=\frac{\sum_{i=1}^{n}\left(\left(\mu_{i k}\right)^{w} * X_{i j}\right.}{\sum_{i j}^{n}\left(\mu_{i k}\right)^{w}}
$$

5) Menghitung fungsi objektif pada iterasi

$$
P_{t}=\sum_{i=1}^{n} \sum_{k=1}^{c}\left(\left[\sum_{j=1}^{m}\left(X_{i j}-V_{k j}\right)^{2}\right]\left(\mu_{i k}\right)^{2}\right)
$$

6) Menghitung perubahan martiks partisi

$$
\mu_{k j}=\frac{\left[\sum_{j=1}^{m}\left(x_{i j}-v_{k j}\right)^{2}\right]^{\frac{-1}{w-1}}}{\sum_{k=1}^{c}\left[\sum_{j=1}^{m}\left(x_{i j}-v_{k j}\right)^{2}\right]^{\frac{-1}{w-1}}}
$$

7) Mengecek kondisi berhenti.

\section{Hasil Dan Pembahasan}

Penelitian menggunakan data alumni yang lukus melalui jalur SNMPTN di SMA Negeri 5 Kota Bnegkulu pada tahun 2019 dan 2020), dimana teknik yang akan digunakan sesuai dengan metode Fuzzy CMeans. Dengan hasil dapat mengetahui siapa yang masuk dalam kluster tinggi, sedang, rendah. Dapat dilihat berdasarkan Data yang dilampirkan pada Tabel data di bawah ini

\begin{tabular}{|l|c|c|c|}
\hline Nama Siswa & C1 & C2 & C3 \\
\hline Izzah Azizah & 0,2 & 0,3 & 0,5 \\
\hline Safitri Anggraini & 0,2 & 0,3 & 0,5 \\
\hline Defriani Yolanda Utami & 0,4 & 0,2 & 0,4 \\
\hline Bambang Kurniawan Cibro & 0,3 & 0,3 & 0,4 \\
\hline Ika Puji Lestari & 0,3 & 0,4 & 0,3 \\
\hline Satria Dimas Syaiful & 0,5 & 0,2 & 0,3 \\
\hline Marchelia Zafira & 0,3 & 0,3 & 0,4 \\
\hline Titis Yoga Safitri & 0,2 & 0,4 & 0,4 \\
\hline Delsa Ardianti & 0,2 & 0,3 & 0,5 \\
\hline Riesa Aliah Tuhfan & 0,4 & 0,2 & 0,4 \\
\hline
\end{tabular}

Tabel 2. Hasil Bilangan Random $U_{i k}$ 
Volume 11 No. 2 | Agustus 2021: 104-111

Setelah membangkitkan bilangan random $\mathrm{U}_{\mathrm{ik}}$ maka kita harus mencari pusat kluster per kluster

\begin{tabular}{|c|c|c|c|c|c|c|c|}
\hline \multirow[t]{2}{*}{ Nama Siswa } & \multirow{2}{*}{$\mathrm{U}_{\mathrm{ik}}$} & \multirow{2}{*}{$\left(\mu_{i k}\right)^{w}$} & \multicolumn{2}{|c|}{$2 \times 1]$} & \multicolumn{2}{|c|}{$\left(\mu_{i k}\right)^{w} * X_{i j}$} & \multirow{2}{*}{$\begin{array}{l}\sum_{i=1}^{n}\left(\left(\mu_{i k}\right)^{w}\right. \\
* X_{i j}\end{array}$} \\
\hline & & & $\begin{array}{c}\text { Atribut } \\
1\end{array}$ & $\begin{array}{c}\text { Atribut } \\
2\end{array}$ & $\begin{array}{c}\text { Atribut } \\
1\end{array}$ & $\begin{array}{c}\text { Atribut } \\
2\end{array}$ & \\
\hline Izzah Azizah & 0,2 & 0,04 & 0 & 87,93 & 0 & 3,5172 & 3,5172 \\
\hline Safitri Anggraini & 0,2 & 0,04 & 0 & 85,00 & 0 & 3,4 & 3,4 \\
\hline $\begin{array}{l}\text { Defriani } \quad \text { Yolanda } \\
\text { Utami }\end{array}$ & 0,4 & 0,16 & 0 & 88,00 & 0 & 14,08 & 14,08 \\
\hline $\begin{array}{l}\text { Bambang } \\
\text { Kumiawan Cibro }\end{array}$ & 0,3 & 0,09 & 3 & 88,86 & 0,27 & 7,9974 & 8,2674 \\
\hline Ika Puji Lestari & 0,3 & 0,09 & 0 & 88,86 & 0 & 7,9974 & 7,9974 \\
\hline $\begin{array}{l}\text { Satria } \quad \text { Dimas } \\
\text { Syaiful }\end{array}$ & 0,5 & 0,25 & 1 & 88,64 & 0,25 & 22,16 & 22,41 \\
\hline Marchelia Zafira & 0,3 & 0,09 & 0 & 89,79 & 0 & 8,0811 & 8,0811 \\
\hline Titis Yoga Safitri & 0,2 & 0,04 & 0 & 91,36 & 0 & 3,6544 & 3,6544 \\
\hline Delsa Ardianti & 0,2 & 0,04 & 1 & 88,07 & 0,04 & 3,5228 & 3,5628 \\
\hline Riesa Aliah Tuhfan & {$[0,7$} & 0,16 & 0 & 89,36 & 0 & 14,2976 & 14,2976 \\
\hline
\end{tabular}

Tabel 3. Cluster I Center $\mathrm{V}_{\mathrm{kj}}$

$$
\begin{gathered}
V_{k j}=\frac{\sum_{i=1}^{n}\left(\left(\mu_{i k}\right)^{w} * X_{i j}\right.}{\sum_{i j}^{n}\left(\mu_{i k}\right)^{w}}=\frac{89,2679}{1} \\
=89,2679
\end{gathered}
$$

\begin{tabular}{|c|c|c|c|c|c|c|c|}
\hline \multirow[t]{2}{*}{ Nama Siswa } & \multirow{2}{*}{$\mathrm{U}_{\mathrm{ik}}$} & \multirow{2}{*}{$\left(\mu_{i k}\right)^{w}$} & \multicolumn{2}{|c|}{$X_{i j}$} & \multicolumn{2}{|c|}{$\left(\mu_{i k}\right)^{w} * X_{i j}$} & \multirow{2}{*}{$\begin{array}{l}\sum_{i=1}^{n}\left(\left(\mu_{i k}\right)^{w}\right. \\
* X_{i j}\end{array}$} \\
\hline & & & $\begin{array}{c}\text { Atribut } \\
1\end{array}$ & $\begin{array}{c}\text { Atribut } \\
2\end{array}$ & $\begin{array}{c}\text { Atribut } \\
1\end{array}$ & $\begin{array}{c}\text { Atribut } \\
2\end{array}$ & \\
\hline Izzah Azizah & 0,3 & 0,09 & 0 & 87,93 & 0 & 7,9137 & 7,9137 \\
\hline Safitri Anggraini & 0,3 & 0,09 & 0 & 85,00 & 0 & 7,65 & 7,65 \\
\hline $\begin{array}{l}\text { Definani Yolanda } \\
\text { Utami }\end{array}$ & 0,2 & 0,04 & 0 & 88,00 & 0 & 3,52 & 3,52 \\
\hline $\begin{array}{l}\text { Bambang } \\
\text { Kumiawan Cibro }\end{array}$ & 0,3 & 0,09 & 3 & 88,86 & 0,27 & 7,9974 & 8,2674 \\
\hline Ika Puij Lestari & 0,4 & 0,16 & 0 & 88,86 & 0 & 14,2176 & 14,2176 \\
\hline Satria Dimas Syaiful & 0,2 & 0,04 & 1 & 88,64 & 0,04 & 3,5456 & 3,5856 \\
\hline Marchelia Zafira & 0,3 & 0,09 & 0 & 89,79 & 0 & 8,0811 & 8,0811 \\
\hline Titis Yoga Safitri & 0,4 & 0,16 & 0 & 91,36 & 0 & 14,6176 & 14,6176 \\
\hline Delsa Ardianti & 0,3 & 0,09 & 1 & 88,07 & 0,09 & 7,9263 & 8,0163 \\
\hline Riesa Aliah Tuhfan & 0,2 & 0,04 & 0 & 89,36 & 0 & 3,5744 & 3,5744 \\
\hline
\end{tabular}

Tabel 3.4. Cluster II Center $V_{k j}$

\begin{tabular}{|c|c|c|c|c|c|c|c|}
\hline \multirow[t]{2}{*}{ Nama Siswa } & \multirow{2}{*}{$\mathrm{U}_{\mathrm{ik}}$} & \multirow{2}{*}{$\left(\mu_{i k}\right)^{w}$} & \multicolumn{2}{|c|}{$X_{i j}$} & \multicolumn{2}{|c|}{$\left(\mu_{i k}\right)^{w} * X_{i j}$} & \multirow{2}{*}{$\begin{array}{l}\sum_{i=1}^{n}\left(\left(\mu_{i k}\right)^{w}\right. \\
* X_{i j}\end{array}$} \\
\hline & & & $\begin{array}{c}\text { Atribut } \\
1\end{array}$ & $\begin{array}{c}\text { Atribut } \\
2\end{array}$ & $\begin{array}{c}\text { Atribut } \\
1\end{array}$ & $\begin{array}{c}\text { Atribut } \\
2\end{array}$ & \\
\hline Izzah Azizah & 0,5 & 0,25 & 0 & 87,93 & 0 & 21,9825 & 21,9825 \\
\hline Safitri Anggraini & 0,5 & 0,25 & 0 & 85,00 & 0 & 21,25 & 21,25 \\
\hline $\begin{array}{l}\text { Defriani Yolanda } \\
\text { Utami }\end{array}$ & 0,4 & 0,16 & 0 & 88,00 & 0 & 14,08 & 14,08 \\
\hline $\begin{array}{l}\text { Bambang } \\
\text { Kumiawan Cibro }\end{array}$ & 0,4 & 0,16 & 3 & 88,86 & 0,48 & 14,2176 & 14,6976 \\
\hline Ika Puji Lestari & 0,3 & 0,09 & 0 & 88,86 & 0 & 7,9974 & 7,9974 \\
\hline $\begin{array}{ll}\text { Satria } & \text { Dimas } \\
\text { Syaiful } & \end{array}$ & 0,3 & 0,09 & 1 & 88,64 & 0,09 & 7,9776 & 8,0676 \\
\hline Marchelia Zafira & 0,4 & 0,16 & 0 & 89,79 & 0 & 14,3664 & 14,3664 \\
\hline Titis Yoga Safitri & 0,4 & 0,16 & 0 & 91,36 & 0 & 14,6176 & 14,6176 \\
\hline Delsa Ardianti & 0,5 & 0,25 & 1 & 88,07 & 0,25 & 22,0175 & 22,2675 \\
\hline $\begin{array}{l}\text { Riesa Aliah } \\
\text { Tuhfan }\end{array}$ & 0,4 & 0,16 & 0 & 89,36 & 0 & 14,2976 & 14,2976 \\
\hline
\end{tabular}

$$
\begin{gathered}
V_{k j}=\frac{\sum_{i=1}^{n}\left(\left(\mu_{i k}\right)^{w} * X_{i j}\right.}{\sum_{i j}^{n}\left(\mu_{i k}\right)^{w}}=\frac{79,4437}{0,89} \\
=89,26258
\end{gathered}
$$

Tabel 4. Cluster III Center $\mathrm{V}_{\mathrm{kj}}$

$$
\begin{aligned}
V_{k j}=\frac{\sum_{i=1}^{n}\left(\left(\mu_{i k}\right)^{w} * X_{i j}\right.}{\sum_{i j}^{n}\left(\mu_{i k}\right)^{w}} \\
=\frac{153,6242}{1,73} \\
=88,80012
\end{aligned}
$$

\begin{tabular}{|c|c|}
\hline $\mathbf{V}_{\mathbf{k j}}$ & Jumlah Alumni \\
\hline 1 & 89,2679 \\
\hline 2 & 89,26258 \\
\hline 3 & 88,80012 \\
\hline
\end{tabular}

Tabel 5. Cluster Center

Jadi untuk pusat kluster $\mathrm{C} 1$ adalah 89,2679 dan pusat kluster C2 adalah 89,26258 dan untuk pusat kluster C3 adalah 88,80012. Setelah mendapatkan pusat kluster kita mencari nilai Fungsi Objektifnya

\begin{tabular}{|l|c|c|c|c|}
\hline \multirow{2}{*}{ Nama Siswa } & \multicolumn{2}{|c|}{$\mathbf{X}_{\text {ij }}$} & $\mathbf{V}_{\mathbf{k j}}$ & $\mathbf{U}_{\text {ik }}$ \\
\cline { 2 - 3 } & Atribut 1 & $\begin{array}{c}\text { Atribut } \\
\mathbf{2}\end{array}$ & & \\
\hline Izzah Azizah & 0 & 87,93 & 89,2679 & 0,2 \\
\hline Safitri Anggraini & 0 & 85,00 & 89,2679 & 0,2 \\
\hline $\begin{array}{l}\text { Defriani Yolanda } \\
\text { Utami }\end{array}$ & 0 & 88,00 & 89,2679 & 0,4 \\
\hline $\begin{array}{l}\text { Bambang Kumiawan } \\
\text { Cibro }\end{array}$ & 3 & 88,86 & 89,2679 & 0,3 \\
\hline Ika Puji Lestari & 0 & 88,86 & 89,2679 & 0,3 \\
\hline Satria Dimas Syaiful & 1 & 88,64 & 89,2679 & 0,5 \\
\hline Marchelia Zafira & 0 & 89,79 & 89,2679 & 0,3 \\
\hline Titis Yoga Safitri & 0 & 91,36 & 89,2679 & 0,2 \\
\hline Delsa Ardianti & 1 & 88,07 & 89,2679 & 0,2 \\
\hline Riesa Aliah Tuhfan & 0 & 89,36 & 89,2679 & 0,4 \\
\hline
\end{tabular}

Tabel 6. Fungsi Objektif Cluster I (1) 
Volume 11 No. 2 | Agustus 2021: 104-111

\begin{tabular}{|l|c|c|}
\hline \multicolumn{1}{|c|}{ Nama Siswa } & $\sum_{\boldsymbol{j}=1}^{m}\left(\boldsymbol{X}_{\boldsymbol{i j}}-\boldsymbol{V}_{\boldsymbol{k}}\right)^{\mathbf{2}}$ & $\left(\boldsymbol{\mu}_{\boldsymbol{i k}}\right)^{\mathbf{2}}$ \\
\hline Izzah Azizah & 7970,548 & 0,04 \\
\hline Safitri Anggraini & 7986,973 & 0,04 \\
\hline Defriani Yolanda Utami & 7970,366 & 0,16 \\
\hline Bambang Kumiawan Cibro & 7442,317 & 0,09 \\
\hline Ika Puji Lestari & 7968,924 & 0,09 \\
\hline Satria Dimas Syaiful & 7791,616 & 0,25 \\
\hline Marchelia Zafira & 7969,031 & 0,09 \\
\hline Titis Yoga Safitri & 7973,135 & 0,04 \\
\hline Delsa Ardianti & 7792,657 & 0,04 \\
\hline Riesa Aliah Tuhfan & 7968,766 & 0,16 \\
\hline
\end{tabular}

Tabel 7. Fungsi Objektif Cluster I (2)

\begin{tabular}{|l|c|}
\hline \multicolumn{1}{|c|}{ Nama Siswa } & Fungsi Objektif \\
\hline Izzah Azizah & 318,8219 \\
\hline Safitri Anggraini & 319,4789 \\
\hline Defriani Yolanda Utami & 1275,258 \\
\hline Bambang Kumiawan Cibro & 669,8085 \\
\hline Ika Puji Lestari & 717,2032 \\
\hline Satria Dimas Syaiful & 1947,904 \\
\hline Marchelia Zafira & 717,2128 \\
\hline Titis Yoga Safitri & 318,9254 \\
\hline Delsa Ardianti & 311,7063 \\
\hline Riesa Aliah Tuhfan & 1275,003 \\
\hline
\end{tabular}

$$
\begin{gathered}
\text { Tabel 3.8. Fungsi Objektif Cluster I (3) } \\
\begin{array}{c}
P_{t} \text { Cluster } I=\sum_{i=1}^{n} \sum_{k=1}^{c}\left(\left[\sum_{j=1}^{m}\left(X_{i j}-V_{k j}\right)^{2}\right]\left(\mu_{i k}\right)^{2}\right) \\
P_{t} \text { Cluster } I=7871,322
\end{array}
\end{gathered}
$$

Setelah mendapatkan Fungsi Objektif Cluster I selanjutnya Mencari Fungsi Objektif Cluster II

\begin{tabular}{|l|c|c|c|c|}
\hline \multirow{2}{*}{ Nama Siswa } & \multicolumn{2}{|c|}{$\mathbf{X}_{\text {ij }}$} & $\mathbf{V}_{\mathbf{k j}}$ & \multirow{2}{*}{$\mathbf{U}_{\text {ik }}$} \\
\cline { 2 - 3 } & Atribut 1 & $\begin{array}{c}\text { Atribut } \\
\mathbf{2}\end{array}$ & & \\
\hline Izzah Azizah & 0 & 87,93 & 89,26258 & 0,3 \\
\hline Safitri Anggraini & 0 & 85,00 & 89,26258 & 0,3 \\
\hline $\begin{array}{l}\text { Defriani Yolanda } \\
\text { Utami }\end{array}$ & 0 & 88,00 & 89,26258 & 0,2 \\
\hline $\begin{array}{l}\text { Bambang Kumiawan } \\
\text { Cibro }\end{array}$ & 3 & 88,86 & 89,26258 & 0,3 \\
\hline Ika Puji Lestari & 0 & 88,86 & 89,26258 & 0,4 \\
\hline Satria Dimas Syaiful & 1 & 88,64 & 89,26258 & 0,2 \\
\hline Marchelia Zafira & 0 & 89,79 & 89,26258 & 0,3 \\
\hline Titis Yoga Safitri & 0 & 91,36 & 89,26258 & 0,4 \\
\hline Delsa Ardianti & 1 & 88,07 & 89,26258 & 0,3 \\
\hline Riesa Aliah Tuhfan & 0 & 89,36 & 89,26258 & 0,2 \\
\hline
\end{tabular}

Tabel 9. Fungsi Objektif Cluster II (1)

\begin{tabular}{|l|c|c|}
\hline \multicolumn{1}{|c|}{ Nama Siswa } & $\sum_{j=1}^{m}\left(\boldsymbol{X}_{i j}-\boldsymbol{V}_{\boldsymbol{k}}\right)^{\mathbf{2}}$ & $\left(\boldsymbol{\mu}_{\boldsymbol{i k}}\right)^{\mathbf{2}}$ \\
\hline Izzah Azizah & 7969,584 & 0,09 \\
\hline Safitri Anggraini & 7985,978 & 0,09 \\
\hline Defriani Yolanda Utami & 7969,402 & 0,04 \\
\hline Bambang Kumiawan Cibro & 7441,395 & 0,09 \\
\hline Ika Puji Lestari & 7967,97 & 0,16 \\
\hline Satria Dimas Syaiful & 7790,671 & 0,04 \\
\hline Marchelia Zafira & 7968,086 & 0,09 \\
\hline Titis Yoga Safitri & 7972,207 & 0,16 \\
\hline Delsa Ardianti & 7791,705 & 0,09 \\
\hline Riesa Aliah Tuhfan & 7967,818 & 0,04 \\
\hline
\end{tabular}

Tabel 10. Fungsi Objektif Cluster II (2 )

\begin{tabular}{|l|c|}
\hline \multicolumn{1}{|c|}{ Nama Siswa } & Fungsi Objektif \\
\hline Izzah Azizah & 717,2626 \\
\hline Safitri Anggraini & 718,738 \\
\hline Defriani Yolanda Utami & 318,7761 \\
\hline Bambang Kumiawan Cibro & 669,7255 \\
\hline Ika Puji Lestari & 1274,875 \\
\hline Satria Dimas Syaiful & 311,6268 \\
\hline Marchelia Zafira & 717,1278 \\
\hline Titis Yoga Safitri & 1275,553 \\
\hline Delsa Ardianti & 701,2535 \\
\hline Riesa Aliah Tuhfan & 318,7127 \\
\hline
\end{tabular}

$$
\begin{gathered}
\text { Tabel 3.11. Fungsi Objektif Cluster II (3) } \\
P_{t} \text { Cluster II }=\sum_{i=1}^{n} \sum_{k=1}^{c}\left(\left[\sum_{j=1}^{m}\left(X_{i j}-V_{k j}\right)^{2}\right]\left(\mu_{i k}\right)^{2}\right)
\end{gathered}
$$

$P_{t}$ Cluster $I I=7023,651$

Setelah mendapatkan Fungsi Objektif Cluster I selanjutnya Mencari Fungsi Objektif Cluster II

\begin{tabular}{|l|c|c|c|c|}
\hline \multirow{2}{*}{ Nama Siswa } & \multicolumn{2}{|c|}{$\mathbf{X}_{\mathbf{i j}}$} & $\mathbf{V}_{\mathbf{k j}}$ & $\mathbf{U}_{\text {ik }}$ \\
\cline { 2 - 3 } & Atribut l & $\begin{array}{c}\text { Atribut } \\
\mathbf{2}\end{array}$ & & \\
\hline Izzah Azizah & 0 & 87,93 & 88,80012 & 0,5 \\
\hline Safitri Anggraini & 0 & 85,00 & 88,80012 & 0,5 \\
\hline $\begin{array}{l}\text { Defriani Yolanda } \\
\text { Utami }\end{array}$ & 0 & 88,00 & 88,80012 & 0,4 \\
\hline $\begin{array}{l}\text { Bambang Kurniawan } \\
\text { Cibro }\end{array}$ & 3 & 88,86 & 88,80012 & 0,4 \\
\hline Ika Puji Lestari & 0 & 88,86 & 88,80012 & 0,3 \\
\hline Satria Dimas Syaiful & 1 & 88,64 & 88,80012 & 0,3 \\
\hline Marchelia Zafira & 0 & 89,79 & 88,80012 & 0,4 \\
\hline Titis Yoga Safitri & 0 & 91,36 & 88,80012 & 0,4 \\
\hline Delsa Ardianti & 1 & 88,07 & 88,80012 & 0,5 \\
\hline Riesa Aliah Tuhfan & 0 & 89,36 & 88,80012 & 0,4 \\
\hline
\end{tabular}

Tabel 12. Fungsi Objektif Cluster III (1) 


\begin{tabular}{|l|c|c|}
\hline \multicolumn{1}{|c|}{ Nama Siswa } & $\sum_{j=1}^{m}\left(\boldsymbol{X}_{\boldsymbol{i} j}-\boldsymbol{V}_{\boldsymbol{k} \boldsymbol{j}}\right)^{2}$ & $\left(\boldsymbol{\mu}_{\boldsymbol{i k}}\right)^{2}$ \\
\hline Izzah Azizah & 7886,218 & 0,25 \\
\hline Safitri Anggraini & 7899,902 & 0,25 \\
\hline Defriani Yolanda Utami & 7886,102 & 0,16 \\
\hline Bambang Kurniawan Cibro & 7361,664 & 0,16 \\
\hline Ika Puji Lestari & 7885,465 & 0,09 \\
\hline Satria Dimas Syaiful & 7708,887 & 0,09 \\
\hline Marchelia Zafira & 7886,441 & 0,16 \\
\hline Titis Yoga Safitri & 7892,014 & 0,16 \\
\hline Delsa Ardianti & 7709,394 & 0,25 \\
\hline Riesa Aliah Tuhfan & 7885,775 & 0,16 \\
\hline
\end{tabular}

Tabel 13. Fungsi Objektif Cluster III (2)

\begin{tabular}{|l|c|}
\hline \multicolumn{1}{|c|}{ Nama Siswa } & Fungsi Objektif \\
\hline Izzah Azizah & 1971,555 \\
\hline Safitri Anggraini & 1974,976 \\
\hline Defriani Yolanda Utami & 1261,776 \\
\hline Bambang Kumiawan Cibro & 1177,866 \\
\hline Ika Puji Lestari & 709,6918 \\
\hline Satria Dimas Syaiful & 693,7998 \\
\hline Marchelia Zafira & 1261,831 \\
\hline Titis Yoga Safitri & 1262,722 \\
\hline Delsa Ardianti & 1927,349 \\
\hline Riesa Aliah Tuhfan & 1261,724 \\
\hline
\end{tabular}

Tabel 3.14. Fungsi Objektif Cluster III (3)

$$
\begin{gathered}
P_{t} \text { Cluster III }=\sum_{i=1}^{n} \sum_{k=1}^{c}\left(\left[\sum_{j=1}^{m}\left(X_{i j}-V_{k j}\right)^{2}\right]\left(\mu_{i k}\right)^{2}\right) \\
P_{t} \text { Cluster III }=13503,29
\end{gathered}
$$

Untuk Nilai Fungsi Objektif Cluster I adalah 7871,322 untuk Fungsi Objektif Cluster II adalah 7023,651 dan Fungsi Objektif Cluster III adalah 13503,29. Selanjutnya mencari nilai Perubahan Matrik partisi

\begin{tabular}{|l|c|c|c|}
\hline \multicolumn{1}{|c|}{ Nama Siswa } & Cl & C2 & C3 \\
\hline Izzah Azizah & 24,68877 & 9,792301 & 6,849057 \\
\hline Safitri Anggraini & 24,638 & 9,772199 & 6,837193 \\
\hline Defriani Yolanda Utami & 6,172335 & 22,03318 & 10,70181 \\
\hline Bambang Kumiawan Cibro & 11,7516 & 10,48736 & 11,4642 \\
\hline Ika Puji Lestari & 10,97502 & 5,509285 & 19,02698 \\
\hline Satria Dimas Syaiful & 4,040919 & 22,53866 & 19,4628 \\
\hline Marchelia Zafira & 10,97488 & 9,794142 & 10,70135 \\
\hline Titis Yoga Safitri & 24,68076 & 5,506357 & 10,69379 \\
\hline Delsa Ardianti & 25,25237 & 10,01585 & 7,006148 \\
\hline Riesa Aliah Tuhfan & 6,173573 & 22,03756 & 10,70225 \\
\hline
\end{tabular}

Tabel 15. Perubahan Matrik Partisi

Dari perubahan matrik partisi bisa mendapatkan hasil clusternya yang terbagi 3 cluster $\mathrm{c} 1, \mathrm{c} 2$ dan $\mathrm{c} 3$

\begin{tabular}{|l|c|c|}
\hline Nama Siswa & $\begin{array}{l}\text { Perguruan } \\
\text { Tinggi }\end{array}$ & Kelompok \\
\hline Izzah Azizah & UNIB & $\mathrm{C} 3$ \\
\hline Safitri Anggraini & UNIB & $\mathrm{C} 3$ \\
\hline $\begin{array}{l}\text { Defriani Yolanda } \\
\text { Utami }\end{array}$ & UNIB & $\mathrm{C} 1$ \\
\hline $\begin{array}{l}\text { Bambang } \\
\text { Kurniawan Cibro }\end{array}$ & $\mathrm{IPB}$ & $\mathrm{C} 2$ \\
\hline Ika Puji Lestari & UNS & $\mathrm{C} 2$ \\
\hline $\begin{array}{l}\text { Satria Dimas } \\
\text { Syaiful }\end{array}$ & UNIB & $\mathrm{C} 1$ \\
\hline Marchelia Zafira & $\begin{array}{l}\text { Universitas } \\
\text { Brawijaya }\end{array}$ & $\mathrm{C} 2$ \\
\hline Titis Yoga Safitri & UNDIP & $\mathrm{C} 2$ \\
\hline Delsa Ardianti & UNIB & $\mathrm{C} 3$ \\
\hline Riesa Aliah Tuhfan & $\begin{array}{l}\text { Universitas } \\
\text { Brawijaya }\end{array}$ & $\mathrm{C} 1$ \\
\hline
\end{tabular}

Tabel 16. Hasil Cluster

untuk $\mathrm{C} 1$ adalah nilai Cluster Tinggi yang terdiri dari 3 orang

\begin{tabular}{|l|c|}
\hline Nama Siswa & Perguruan Tinggi \\
\hline $\begin{array}{l}\text { Defriani Yolanda } \\
\text { Utami }\end{array}$ & UNIB \\
\hline $\begin{array}{l}\text { Satria Dimas } \\
\text { Syaiful }\end{array}$ & UNIB \\
\hline Riesa Aliah Tuhfan & Universitas Brawijaya \\
\hline
\end{tabular}
Tabel 17. Cluster I

untuk $\mathrm{C} 2$ adalah nilai Cluster sedang yang terdiri 4 dari orang

\begin{tabular}{|l|c|}
\hline Nama Siswa & $\begin{array}{l}\text { Perguruan } \\
\text { Tinggi }\end{array}$ \\
\hline $\begin{array}{l}\text { Bambang Kurniawan } \\
\text { Cibro }\end{array}$ & IPB \\
\hline Ika Puji Lestari & $\begin{array}{c}\text { Univeristas } \\
\text { Sebelas Maret }\end{array}$ \\
\hline Marchelia Zafira & $\begin{array}{c}\text { Universitas } \\
\text { Brawijaya }\end{array}$ \\
\hline Titis Yoga Safitri & UNDIP \\
\hline
\end{tabular}

Tabel 18. Cluster II

untuk $\mathrm{C} 3$ adalah nilai Cluster rendah yang terdiri dari 3 orang

\begin{tabular}{|l|c|}
\hline Nama Siswa & Perguruan Tinggi \\
\hline Izzah Azizah & UNIB \\
\hline Safitri Anggraini & UNIB \\
\hline Delsa Ardianti & UNIB \\
\hline
\end{tabular}

Tabel 19. Cluster III

Dari tabel di atas mendapatkan 3 kelompok yang terdiri dari $\mathrm{C} 1$ adalah cluster tinggi yang terdiri dari 3 orang, $\mathrm{C} 2$ adalah untuk cluster sedang/menenggah yang terdiri dari 4 orang dan $\mathrm{C} 3$ untuk cluster rendah yang terdiri dari 3 orang. 


\subsection{Antar Muka Program}

Aplikasi Data Penerimaan Siswa Pada Perguruan Tinggi Melalui Jalur SNMPTN dibuat menggunakan bahasa pemrograman Visual Basic .Net dan Database SQL Server 2008 dengan menerapkan algoritma Fuzzy C-Means. Visual Studio adalah IDE (Integrated Development Environment) yang dapat digunakan untuk mengembangkan aplikasi-aplikasi Windows [6].

Adapun antarmuka Aplikasi Data Penerimaan Siswa Pada Perguruan Tinggi Melalui Jalur SNMPTN, antara lain :

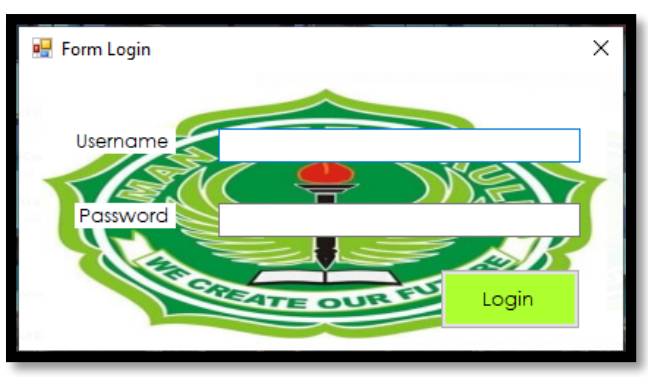

Gambar 2. Menu Login

Gambar 2 merupakan Menu login yang digunakan untuk membatasi akses penggunaan aplikasi melalui username dan password. Sehingga admin harus memasukkan username dan password yang benar agar dapat masuk ke menu utama agar dapat mengakses secara keseluruhan dari Aplikasi Data Penerimaan Siswa Pada Perguruan Tinggi Melalui Jalur SNMPTN. Adapun form menu login seperti

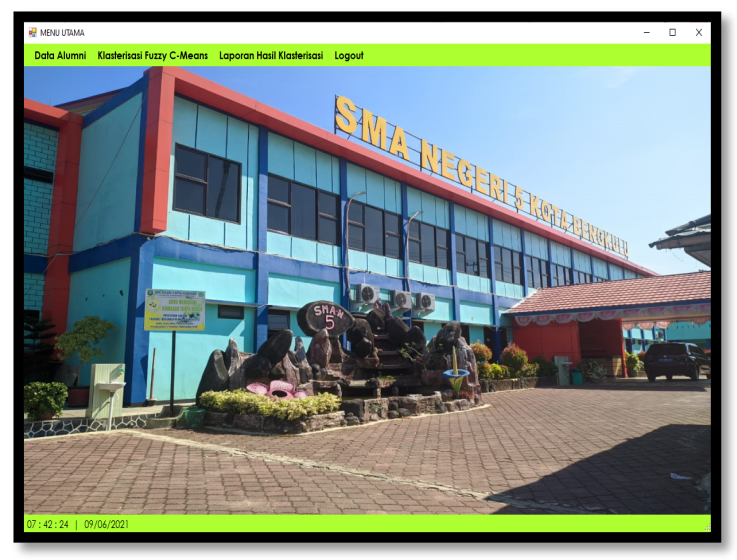

Gambar 3. Menu Utama

Gambar 3 merupakan menu uatama yang memiliki beberapa sub menu yang dapat diakses oleh admin untuk melakukan pengolahan data pada Aplikasi Data Penerimaan Siswa Pada Perguruan Tinggi Melalui Jalur SNMPTN, yaitu data alumni, klasterisasi Fuzzy C-Means, laporan hasil klasterisasi, dan logout data yang memiliki fungsi yang berbeda-beda.

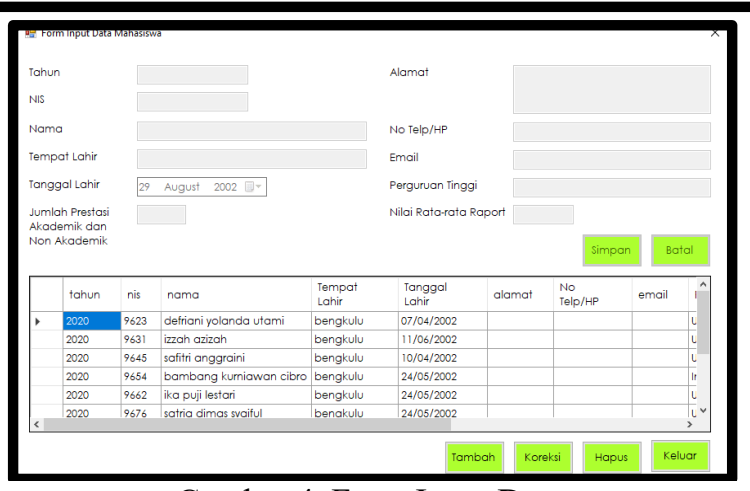

Gambar 4. Form Input Data

Gambar 4 merupakan Form input data SNMPTN yang digunakan untuk mengelola data alumni di SMA Negeri 5 Kota Bengkulu, dimana telah disediakan field untuk mengentri data dan dapat melakukan proses tambah, koreksi, hapus data pada form

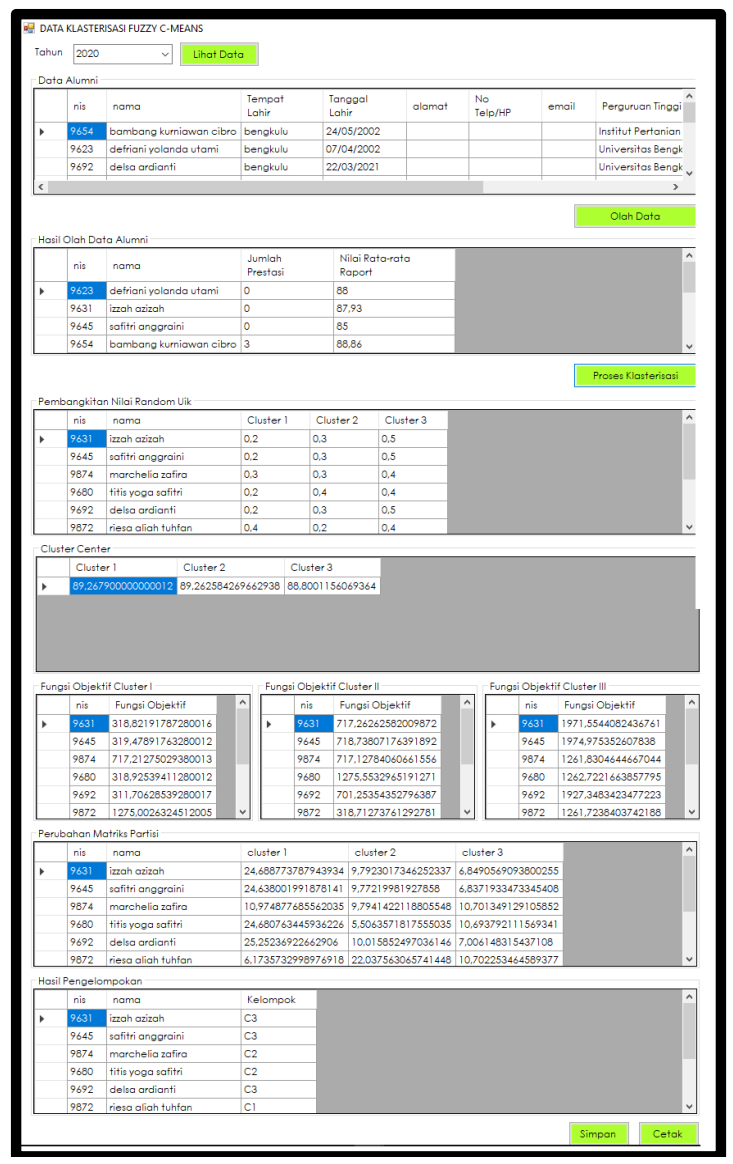

Gambar 5. Klasterisasi Fuzzy C-Means

Gambar 5 merupakan form klasterisasi fuzzy cmeans yang digunakan untuk menganalisis data alumni melalui pendekatan metode K-Means Clustering dimana hasil olah data tersebut akan dibagi menjadi 3 cluster yaitu tinggi, sedang, dan renda. 


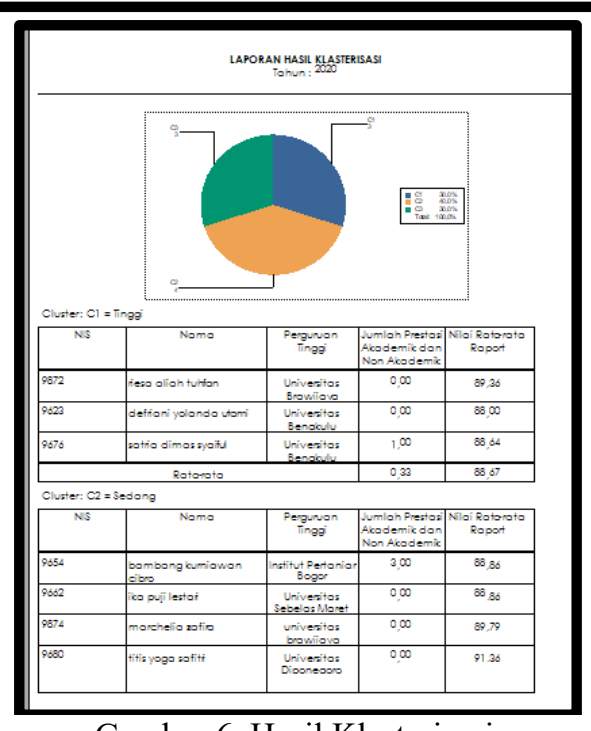

Gambar 6. Hasil Klasterisasi

Gambar 6 adalah hasil klastrerisasi yang memberikan informasi hasil klasterisasi data alumni berdasarkan atribut jumlah prestasi akademik dan non akademik serta nilai rata-rata Raport.

\subsection{Hasil Pengujian Blackbox}

Pengujian blackbox (blackbox testing) adalah salah satu metode pengujian perangkat lunak yang berfokus pada sisi fungsionalitas, khususnya pada input dan output Aplikasi Data Penerimaan Siswa Pada Perguruan Tinggi Melalui Jalur SNMPTN

Berdasarkan hasil pengujian yang telah dilakukan, Aplikasi Data Penerimaan Siswa Pada Perguruan Tinggi Melalui Jalur SNMPTN dapat memberikan informasi hasil pengelompokan data yang dibagi menjadi 3 kelompok yaitu tinggi, sedang dan rendah.

\begin{tabular}{|l|l|l|l|}
\hline No & Skenario Pengujian & \multicolumn{1}{|c|}{ Test Case } & \multicolumn{1}{|c|}{ Hasil Pengujian } \\
\hline 1. & $\begin{array}{l}\text { Melakukan login } \\
\text { dengan memasukkan } \\
\text { usemame dan } \\
\text { password yang benar }\end{array}$ & Form login & $\begin{array}{l}\text { Sistem berhasil menerima } \\
\text { login, dan menampilkan } \\
\text { pesan serta menu utama dari } \\
\text { aplikasi secara otomatis }\end{array}$ \\
\hline 2 & $\begin{array}{l}\text { Melakukan } \\
\text { pengolahan data } \\
\text { alumni }\end{array}$ & Form alumni & $\begin{array}{l}\text { Sistem berhasil menyimpan, } \\
\text { mengoreksi, } \\
\text { menghapus data alumni }\end{array}$ \\
\hline 4 & $\begin{array}{l}\text { Melakukan } \\
\text { klasterisasi fuzzy c- } \\
\text { means }\end{array}$ & $\begin{array}{l}\text { Form } \\
\text { klasterisasi } \\
\text { fuzzy c-means }\end{array}$ & data \\
proses clustering..
\end{tabular}

Tabel 20. Hasil Blackbox

\section{Kesimpulan}

Setelah melakukan analisis terhadap sampel data penerimaan siswa pada perguruan tinggi melalui jalur SNMPTN pada Tahun 2019 dan 2020, maka diperoleh hasil Cluster C1 (Tinggi) pada tahun 2019 memiliki 20 orang alumni dengan rata-rata Jumlah Prestasi 1,00 dan Raport 87,37 dan pada tahun 2020 memiliki 16 orang alumni dengan rata-rata Jumlah Prestasi 0,61 dan Raport 87,98.Cluster C2 (Sedang) pada tahun 2019 memiliki 13 orang alumni dengan rata-rata Jumlah Prestasi 0,31 dan Raport 87,45 dan pada tahun 2020 memiliki 13 orang alumni dengan rata-rata Jumlah Prestasi 0,38 dan Raport 87,97.Cluster C3 (Rendah) pada tahun 2019 memiliki 14 orang alumni dengan rata-rata Jumlah Prestasi 0,21 dan Raport 88,02 dan pada tahun 2020 memiliki 15 orang alumni dengan rata-rata Jumlah Prestasi : 0,40 dan Raport 88,59.

\section{Daftar Rujukan}

[1]. Sasmito, ginajar wiro. 2017. Penerapan metode waterfall pada desain sistem infotmasi geografis industri kabupaten tegal . Jurnal Informatika : Jurnal Pengembangan IT(JPIT), Vol 2, No. 1, Januari 2017

[2] Sikumbang, Erma Delima. 2018. Penerapan Data Mining Penjualan Sepatu Menggunakan Metode Algoritma Apriori. Jurnal Teknik Komputer Vol.4 No.1 Februari 2018.

[3]. Sanusi, Wahidah. Zaky, Ahmad. Afni, Besse Nur. 2019. Analisis Fuzzy C-Means dan Penerapannya Dalam Pengelompokan Kabupaten/Kota di Provinsi Sulawesi Selatan Berdasarkan Faktor-faktor Penyebab Gizi Buruk. Journal Of Mathematics, Computation, and Statistics Vol.2 No.1

[4]. Ramadhan, Aditya. Dkk. 2017. Perbandingan KMeans dan Fuzzy C-Means Untuk Pengelompokan Data User Knowledge Modeling. Seminar Nasional Teknologi Informasi, Komunikasi, dan Industri (SNTIKI) Fakultas Sains dan Teknologi UIN Sultan Syarif Kasim Riau Pekanbaru 18-19 Mei 2019. ISSN 2579-7271.

[5]. Rahakbauw. Dkk. 2017. Implementasi Fuzzy Fuzzy C-Means Dalam Penentuan Beasiswa. Jurnal Ilmu Matematika dan Terapan Vol.11 No.1 Maret 2017

[6]. Enterprise, Jubilee. 2015. Pengenalan Visual Studio 2013. PT. Elex Media Komputindo : Jakarta. 